\title{
Illustrative documents
}

The original spelling and format of these documents has been preserved wherever possible, with alterations made only to clarify the text. Punctuation has been modernised where it elucidates the sense of the letter, and capitalisation has been modernised throughout. All contractions have been silently expanded; other alterations and author's interpolations are in square brackets.

\section{Clarke (ed.), Life of James the Second, ii. 342-3: James II and VII to the Scottish Convention, 19 February/1 March 1689}

My Lords and Gentlemen, whereas we have been informed that you, the peers and representatives of shires and boroughs of that our antient kingdom, who are to meet togather at our good town of Edinburgh some time of this instant March, by the usurped authority of the Prince of Orange [William III and II]; we think fit to let you know, that as we have at all times relyd upon the faithfullness and affection of you, our antient people, so much, that in our greatest misfortunes heretofore, we had recours to your assistance with good success to our affairs, so now again, we require of you, to support our Royal intrest, expecting from you what becomes faithful and loyal subjects; generous and honest men; that will neither suffer your selves to be cojol'd nor frighted into any action, not becomeing true hearted Scotchmen. And that to support the honour of the nation, you will contemn the base example of disloyal men, and eternelize your name by a loyalty sutable to the professions you have ever made to us; in doing thereof you will chuse the safest part, since thereby you will evite the danger you must needs undergo, the infamy and disgrace you bring upon your selves in this world, and the condemnation due to the rebellious in the next; and you 
will likewise have the opertunity to secure to yourselves, and your posterity, the gracious promises which we have so often made of secureing your religion, laws, properties and rights, which we are still resolved to performe, as soon as it is possible for us to meet you safely in a Parliament of our antient kingdom: in the mean time fear not to declare for us your lawfull sovereign, who will not fail on our part to give you such speedy and powerfull assistance, as shall not only enable you to defend yourselves from any forreign attempts, but put you in a condition of asserting our right against our enemies, who have depressed the same by the blackest of usurpations, the most unjust as well as most unnaturall attempts, which the almighty God may for a time permit and let the wicked prosper, yet then must bring confusion upon such workers of iniquity; we likewise let you know we shall pardon all such as shall return to their duty before the last day of this month inclusive, and that we shall punish with the rigour of our laws all such as shall stand in rebellion against us or our authority. So, not doubting but that you will declare for us, and suppress whatever may oppose our intrest, and that you will send some of your number to us, with an account of your diligence, and the posture of our affairs, we bid you heartely farewell. Given on board the St Michel, March the first, anno domini 1689. By his Majesty's command. Melfort.

2 T. B. Howell (ed), A Complete Collection of State Trials (33 vols, London, 1816-26), xii. col. 817-19: Sir John Ashton's final, scaffold, declaration, 28 January 1690

Mr Sherif, Having observed that the methods of making speeches at the place of execution were not always attended with the designed successes; and thinking it better to enjoy my last minutes in devotion and holy communion with my God, I have prepared this paper to leave in your hands, as well to assert my principles as to testify my innocency.

As to my religion, I profess, by God's grace, to die in the faith in the which I was baptized: that of the Church of England, in whose communion (nothing doubting of my salvation through the merits of my saviour) I have always thought myself safe and happy. According to her principles and late much esteemed doctrine (though now unhappily exploded) I have regulated my life; believing myself obliged, by my religion, to look upon my rightful, lawful 
Prince (whatever his principles were, or his practises might be) as God's viceregent, and accountable (if guilty of maladministration) to God only, from whom he received his power; and always believing it to be contrary to the laws of God, the Church, and the realm, upon any pretence whatsoever, to take up arms against him. And let all the world take notice in this belief I die. But I have more particular obligations to the king, my master, whom I had the honour to serve, and received many signal favours from him, for 16 years past; so that gratitude (a thing not much esteemed at this time) as well as duty and religion, commanded the utmost service I could pay him. And when I add these considerations: that we were born his liege subjects; that we had solemnly professed our allegiance, and often confirmed it with oaths; that his Majesty's usage, after the Prince of Orange's arrival, was very hard, severe, and (I may say) unjust; and, that all the new methods of settling this nation have hitherto made it more miserable, poor, and more exposed to foreign enemies; and, that the religion we pretend to be fond of preserving is now much more than ever likely to be destroyed. There seemed to me no way to prevent the impending evils, and save these nations from poverty and destruction, but the calling home our injured sovereign, who, as a true father of his country, has (notwithstanding all his provocations and injuries) a natural love and tenderness for all his subjects. And I am so far from repining at the loss of my life, that had I ten thousand I should rather think myself obliged to sacrifice them all than omit any just and honest means to promote so good and necessary a work. And I advise and desire all my fellow subjects to think of their duty and turn to their allegiance, before the severe judgments of God overtake them for their perjury and rebellion. But certainly the good and interest of these nations, abstracted from all other considerations, will ere long convince them of the necessity of doing it.

... Bless, protect and strengthen, O Lord God, my good and gracious king and master! In thy due time let the virtue, goodness, and innocency of the queen, my mistress, make all their enemies blush, and silence the wicked and unjust calumnies that malice and envy have raised against her. Make her and these nations happy in the Prince of Wales; whom from unanswerable and undoubted proofs, I know to be her son. Restore them all, when thou seest fit, to their just rights, and on such a bottom as may support and establish the Church of England, and once more make her flourish, 
notwithstanding what she hath received of late from her prevaricating sons. Forgive, forgive, O Lord, all my enemies; bless all my friends; comfort and support my dear afflicted wife, and poor babes; be thou a husband and a father to them; for their sakes only I could have wished to have lived; but pardon that wish, $\mathrm{O}$ good God, and take my soul into thy everlasting glory! Amen.

\section{Carte 181, ff. 525ar-525br: 'His Majestie's Most Gracious Declaration to all his Loving Subjects', 10/17 April 1693}

Whereas we are most sensible that nothing has contributed so much to our misfortunes, and our people's miseries, as the false and malicious calumnies of our enemies, therefore we have always been, and still are most willing to condescend to such things as after mature deliberation, we have thought most proper for renewing thereof, and most likely to give the fullest satisfaction and clearest prospect of the greatest security to all ranks and degrees of our people, and because we desire rather to be beholding to our subjects' love to us then to any other expedient whatever, for our restoration; we have thought fit to let them know beforehand our royal and sincere intentions; and that whenever our people's united desires, and our circumstances give us the opportunity to come and assert our right, we will come with the Declaration that follows.

James R.

When we reflect upon the calamities of our kingdoms, we are not willing to leave anything unattempted whereby we may reconcile our subjects to their duty, and tho we cannot enter into all the particulars of Grace and goodness which we shall be willing to grant, yet we do hereby assure all our loving subjects that they may depend upon everything that their own representatives shall offer, to make our kingdoms happy. For we have set it before our eyes, as our noblest aim, to do yet more for their constitution, then the most renowned of our ancestors. And as our chiefest interest, to leave no umbrage for jealousie, in relation to religion, liberty and property.

And to encourage all our loving subjects, of what degree or quality soever, to set their hearts and hands to the perfecting of so good a work, and to unite themselves in this only means of establishing the future peace and prosperity of these kingdoms, we have thought fit to publish and declare, that, on our part, we are ready and willing wholly to lay aside all thoughts of animosity 
or resentment for what is past, desiring nothing more then that it should be buried in perpetual oblivion. And do therefore by this our Declaration under our Great Seal, solemnly promise our free pardon and indemnity to all our loving subjects, of what degree or quality soever, who shall not by land or sea oppose us and those we shall think necessary to accompany our own person, in this just attempt to recover our right. Or (in such a number of days after our landing, as we shall hereafter express) shall not resist them who in any part of our dominions shall according to their duty assert and maintain the justice of our cause. Beseeching God to incline the hearts of our people that all effusion of blood may be prevented, and righteousness and mercy take place. And for that end, we further promise to all such as shall come to, and assist us, that we will reward them according to their respective degrees and merits.

We do further declare that we will, with all speed, call together the representative body of our kingdom. And therein will inform ourselves what are the united interests and inclinations of our people, and with their concurrence, will be ready to redress all their grievances, and give all those securities of which they shall stand in need.

We likewise declare, upon our royal word, that we will protect and defend the Church of England, as it is now established by law. And secure to the Members of it, all the churches, universities, colledges and schools, together with their immunities, rights and priviledges.

We also declare, we will with all earnestness recommend to that Parliament such an impartial liberty of conscience, as they shall think necessary for the happiness of these nations.

We further declare, we will not dispense with, or violate the Test. And, as for the dispensing power in other matters, we leave it to be explained and limited by that Parliament.

We declare also, that we will give our royal assent to all such bills as are necessary to secure the frequent calling and holding of Parliaments: the free elections and fair return of members; and provide for impartial tryals; and that we will ratifie and confirme all such laws, made under the present usurpation, as shall be tendered to us by that Parliament.

And in that Parliament we will also consent to everything they shall think necessary to re-establishing the late Act of Settlement of Ireland, how to recompence such of that nation as have followed us 
to the last, and who may suffer by the said re-establisment, according to the degree of their sufferings thereby. Yet so as that the said Act of Settlement may alwais remain intire.

And, if Chimny-Money, or any other part of the revenue of the Crown, has been burthensome to our subjects, we shall be ready to exchange it, for any other assessment that shall be thought more easie.

Thus we have sincerely declared our royal intentions, in terms we think necessary, for setling our subjects' minds, and according to the advice and intimations we have received from great numbers of our loving subjects, of all ranks and degrees, who have adjusted the manner of our coming to regain our own right, and to relieve our people from oppression and slavery.

After this, we suppose it will not be necessary to enumerate the tyrannical violations, and burthens, with which our kingdoms have been oppressed, and are now like to be destroyed.

And whereas our enemies endeavour to affright our subjects with the apprehensions of great sums which must be repaid to France, we positively assure them that our dearest brother the Most Christian King expects no other compensation for what he has done for us than meerly the glory of having succor'd an injur'd Prince.

We only add, that we come to vindicate our own right, and to establish the liberties of our people. And may God give us success in the prosecution of the one, as we sincerely intend the confirmation of the other. James R.

4 Macray (ed.), Correspondence of Colonel N. Hooke, ii. 333-5: Terms concerted by Anne Drummond, Countess of Erroll and the Scots Jacobite Juncto in 1705, passed to Hooke, June 1707

That the spring of the project be lodged in a few persons, nothing of it to be communicat but by consent of all.

That the security of the laws, liberties and religion of the country be provided for to the satisfaction of all candid men who are not poisoned revolutioners.

That the scheme of the securitie be form'd in limiting the prerogative of a Popish King and establishing a clame of right and instrument of government containing the essentiall and warantable conditions by which a prince of that comunion is to be regulat under a failor of the aledgiance of the subject. 
That a convention be caled, and the instrument of government concerted and adjusted before the King enter upon the administration of the government.

That the instrument be confirm'd by the solemn oath of the Prince and the states, bearing a declaration against all ..[blank].. or mental reservation as uterlie inconsistant with human societie, morality, or religion.

That the oath of aledgiance be concerted with relation to the instrument of government.

That the heads of the instrument be laid before the King by a mesenger from the juncto.

That the juncto deall with one another without reserve and with ane intire confidence.

That if the conditions of government be accepted, the design be caryed on with vigor and resolution to the utmost hazard of lives and fortunes.

That the conditions of government be ofered as the humble judgement of the juncto and a necessarie term, without which the restoration is, in the wishings or actings of the people, altogether impracticable.

That if the condition be rejected or declined, the government may be considered as absolutly loosed and subverted, and methods falen upon for a new settlement most conducive to the [well] and good of the nation with respect to the sacred and civil intresst, and of the advantages and disadvantages that doeth or may occurre to it through the measures and conduct of other nations.

\section{Heads of the Instrument of Government}

That no Papist be imployed in places civil, ecclesiasticall, or militarie, without the consent of Parliament.

That no alyance be made, either public or private, without consent of Parliament.

That the officers of state, privie councell, lords of session and justiciarie, be named by Parliament.

That a Parliament be caled and continowed to sitt for the dispatch of publick business and the service of the nation once in three years.

That a libertie of consitience and toleration be setled upon a right foundation. 
5 [Fr Luke Hooke (ed.)] The Secret History of Colonel Hooke's Negotiations in Scotland, in Favour of the Pretender; in 1707. Including the Original Letters and Papers Which passed between the Scotch and Irish Lords and the Courts of Versailles and St. Germains (London, 1760), pp. 178-85.

A Narrative of the Voyage of M. [Charles] FLEMING to Scotland, and of the present state of that kingdom.

Having received an order from the King my master, on the [17/]28th of February, 1708, to set out for Scotland, I left St. Germain on the [18/]29th, charged with instructions, which his Majesty judged necessary for the principal Lords of that kingdom, and was pleased to trust me with. I left Paris the [18 February/]1st of March, and I arrived at Dunkirk on the [20th/]3rd, where the absence of $\mathrm{Mr}$. Canan, whom I was ordered to carry with me to conduct me, hindered my embarking till the 6th, when Mr. Arnott arrived from Paris, to be transported to Scotland, with some instructions of the King my master, lest any misfortune mould happen to me. Count [Claude de] Forbin, and M. [René] Duguay, Intendant of the Marine, judged it proper to send us both off the same evening in different frigates. I went on board the Cigalle, commanded by M. Lotton, which had formerly on two different occasions, sailed from Dunkirk.

Having arrived on the [2nd/]13th within two leagues of the land, I went on board a fishing-boat, that I might not be suspected, and landed at the castle of Slaines, belonging to the Earl of Errol, who received the news I brought him, after which he had sighed so long, with all the joy that might be expected from a man, who had given all the proofs of most extraordinary zeal for the service, being greater than could be required from one less zealous than himself, he having exposed himself and his family to almost inevitable ruin, by receiving into his house all envoys who have been sent to Scotland these four or five years past, the vessels which have been sent thither sailing always directly to his castle. He also furnished to all, without exception, money and horses, necessary to keep up a correspondence throughout the kingdom, and even hired vessels for some persons, which has cost him large sums, and greatly indebted that family.

The Earl of Errol having read the King's instructions, which I put into his hands, instantly dispatched a messenger to Mr. [James] Malcolm [of Grange], a gentleman of known fidelity, and who lived 
very near the mouth of the Firth of Edinburgh, with orders to have a boat ready and pilots, to go on board the first vessel that would give the signal agreed on. This Mr. Malcolm punctually executed, having been on board the Proteus, the only vessel that entered the Firth, for which he has been obliged to keep himself concealed ever since. The same express of the Earl of Errol went afterwards, by his orders, along the coasts of Fife and Lothian, to give notice to the well-affected to have boats and pilots ready, which was so faithfully executed by them, that many of them have been imprisoned on this account.

Upon my arrival he also sent to the Earl Marshal, who living at no great distance, came the same evening, when I gave him the instructions I had for him. He immediately took the necessary measures for giving notice to his friends in that country, and for going to the county of Marr, where he is hereditary great bailiff; and next day he accordingly went thither. As I was ordered to follow the measures which would be prescribed to me by [Errol] and Earl Marshal, in giving notice to the chiefs of the country, and delivering to them the instructions of the King my master, which I had for them, they desired me on the [22nd/]4th to write to Mr. Nicolson, Catholick bishop of that kingdom, to inform him of the present state of affairs, that he might give notice to the Catholicks of the North to hold themselves in readiness. I wrote likewise, by their orders, to the Duchess of Gordon upon the same subject, which she communicated to the Marquis of Huntly, her son, who was then in the North, that he might make every thing ready in the counties of Inverness, Ross, and Lochabar, in which counties he has great interest.

I likewise gave notice to the Laird of Coxtoun, who is well known to the King for his fidelity, and the services which he rendered him in the late war. Having seen the Chevalier [Sir William] Keith and Colonel Gordon, and the Earl of Errol having engaged to give notice to Major-General [Thomas] Buchan, on the [3rd/]14th I left Slaines, which is in the county of Aberdeen. That shire, and all those northward from it, were very zealous for the interests of the King. I passed the shire of Marr without stopping, as the Earl Marshal had engaged to inform them of what was necessary.

On the 16th I arrived at Lord Strathmore's in Angus, and gave him the instructions of the King. He was transported to see affairs in so great forwardness, and sent to some of the chief gentry, in order 
to take the necessary measures at that juncture. He also sent to Lord Panmure, but he was at Edinburgh, on particular business of his own. The King is always sure of him, he having never consented to take the oaths to the present government. The same evening I arrived at Lord Nairne's, in the county of Perth, who expressed great zeal for the service of the King; and as I had a letter of the Earl of Errol for him, that he might inform me of the most proper measures to see his brother the Marquis of Athol, he undertook to conduct me to him. We found that Lord in such a temper as we could wish. For five months before he had all his vassals ready to take arms upon the first news of the King's arrival. He is very powerful, both in the number of his own vassals, and of others, who are bound to join him. He asked of me scveral times, and with great earnestness, the name of the General who was to command them. I found him and all the other chiefs, whom I saw, fully persuaded that it was the Duke of Berwick, for they could not imagine that he could be recalled from Spain for any other purpose, as he was a subject of his Britannic Majesty. They had conceived so great an esteem for him, that I durst not venture to tell them that he was not to be employed in the expedition; but told them, that before his arrival at court, that could not be determined.

Lord Nairne afterwards conducted me to Lord Breadalbane's, who not only engaged to cause his vassals, who are very numerous, to join the King, but also to keep the Argyleshire men, who are looked upon as the most disaffected, so in awe, that the King should meet with no opposition from them. He read the King's instructions, which I gave him, with great joy. From thence I went to Castle Drummond, where I found the Marquis of Drummond and his brother, sons of the Duke of Perth. They received the good news that I brought them, with great joy; and the Marquis immediately sent to give notice to several chiefs of the Highlanders, who have a confidence in him, to hold themselves in readiness, and took also the necessary measures to inform the other chiefs of that country. I next day went to Stirlingshire to Lord Kilsyth's, who was then at Edinburgh, as was also my brother the Earl of Wigtoun, who lives very near that place, though in another shire. The people of Stirlingshire are very unanimous for the King's service, and had united under the command of the Earl of Linlithgow. On the [11th/ $] 22 \mathrm{nd} \mathrm{I} \mathrm{went} \mathrm{to}$ the Laird of Kilmaronock's in Dumbartonshire. He is very zealous in the King's interest, and sent to the Earl of Dundonald his nephew, 
to inform him of the state of affairs. I remained here some days, expecting, with impatience, the news of the King's arrival, who, according to the measures taken when I left Dunkirk, was to have embarked on the [29th/]11th. In a few days a rumour prevailed, that the King had landed in the North, which I could hardly believe, but the report coming from every quarter, I set out for that country, and on my journey I found that, on the same report, the Lairds of Keir, [Touch], and [Garden], with Colonel [William Grahame], had taken the same route. I travelled two days with them; but finding no confirmation of the news, they were obliged to separate, and get home the best way they could. I continued my journey, and met with Lord Nairne, who was returning from the castle of Hamilton, where he had been to speak to the Duchess dowager, the mother of the present Earl of Arran. As the Presbyterian ministers have a great influence with her, there was one in his retinue to gain over the minister of Hamilton, who has great authority with the Duchess. She appeared very zealous for the King's service; but she said she could undertake nothing in the absence of the Earl her son, who was in England on his particular affairs. Though some blamed his being absent at that juncture, yet it is certain that he had taken all the necessary measures to receive the orders and letters that should come to Scotland for him. In effect, he received those which I brought for him, and it is believed that he would have done very considerable service to the King, by the number of horse which he would have brought from the north of England.

It was about this time that the bad success of the enterprize began to be known, by the arrival of the English fleet under admiral Byng in the Firth of Edinburgh; but the well-affected had a difficulty to believe that they would retire, without endeavouring to make a descent at Cromarty, and even after they retired from the northern coast, they flattered themselves that they would sail towards Clyde; but the King's return to Dunkirk, which was known by the public papers, threw the whole country into a consternation that cannot be expressed. I had been a witness of the good disposition of the great part of the kingdom through which I had travelled, and I was well informed of the good intentions of the rest of the nobility, and gentry of the country. Never was seen so universal a joy at Edinburgh, as that which appeared in every body's countenance for three or four days before the King's arrival. The loyal subjects thronged together, and those of the government durst not appear in 
public. They had no confidence in the regular troops, knowing that the best part, both of the officers and soldiers, were well affected to the King. Besides, there was neither powder nor ammunition in the castle of Edinburgh, nor in that of Stirling; and they knew that all the gentry would revolt from the government the moment the King landed. So that it was believed that on the King's arrival, those who adhered to the government, would retire towards Berwick; but when it was known by the Gazettes that the King was returned to Dunkirk, the consternation was so great, that every body appeared distracted. They had received orders, after the instructions that I had given them, not to take arms openly, or appear in the field till the landing of the King. The French fleet had retired, without their receiving any order from the King how they were to act, and they had no chief or person who could take upon him to give them orders. In the mean time, the arrival of the English fleet in the road of Edinburgh, and the retreat of the French, had given new courage to those of the government, who sent heralds to summon the principal nobility and gentry, that were in the King's interest, to appear personally before the privy council, under pain of rebellion; which nevertheless they did not do, till fifteen days after the departure of the French fleet, and after they had heard of its arrival at Dunkirk. It is certain, that nothing could have so irritated the nation in general, as the treatment which the nobility and gentry received, in sending them under a guard to England. This has opened the eyes even of those who were most zealous for the Union, and made them see clearly what they are to expect from a nation, which begins already to treat them with so much inhumanity. And it may be justly said, that the Scottish nation were never known so generally disposed to hazard their lives and fortunes to free themselves from this slavery, if they were put in a condition to act.

Although the greatest number of the chief nobility of the country are at present under confinement, it is nevertheless certain, that there is scarce any considerable family, that has not sons, brothers, or near relations, who would put themselves at the head of their vassals in the common cause, if there was but an opportunity. They are in general persuaded, that his Most Christian Majesty, so universally known and admired for his generosity and greatness of soul, having as it were, engaged them in the cause for which they suffer, will not abandon them, especially as they have failed in nothing on their side of what was required of them. After the fidelity which they 
have shewn to their lawful and natural sovereign, which is certainly augmented by the vigour and firmness of his conduct in the late expedition, nothing so much contributed to make them engage to expose themselves in the manner they have done, as the promises made to them by Colonel Hooke, that his Most Christian Majesty would support them, and not abandon them, and his shewing them the full powers he had to make them that promise.

\section{Macpherson (ed.), Original Papers, ii. 385-6: James to Louis XIV, 7/18 February 1713}

Sire, What terms shall I employ to express my gratitude to your Majesty, before I leave the asylum which you have been pleased to grant me, almost ever since I was born, and which you do not permit me to leave, but in order to procure for me another more suitable, in the present state of your affairs and of my own? Words fail me, to express how my heart is penetrated, by the remembrance of your Majesty's benificence and former kindness towards me. The care you are now pleased to take of me, and of whatever concerns me, crowns the whole, and encourages me, in the sad situation I am in, from the confidence I have, in a generosity that has no example for its continuance, in a wisdom which is accustomed to accomplish the greatest designs, and in a bounty which unweariedly extends itself to me and to my family.

It is with all possible earnestness, that I request your Majesty for the continuance of it, towards me and the Queen my mother [Mary of Modena]; the only person who is left of all those who were most dear to me, and who deserves so much of me, as the best of mothers. Besides, she does not fall short of me in the sentiments of gratitude to your Majesty, with which she herself inspired me, from my tenderest infancy.

When I have assured your Majesty of my most sincere and fervent wishes for your prosperity and happiness, I have nothing further to say, but to conjure your Majesty to be thoroughly persuaded, that you will always find in me the respect, attachment, and, if I can presume to say, the tenderness of a son, a will always ready, not only to follow, but even to go before your own in all things, during the time of my exile; and if I shall ever see myself restored to my dominions, a faithful ally, who will make it his glory and his happiness to concur with the first designs of a king who does honour to royalty. 
7 MS Carte 210, ff. 409-10: James's personally written reply to Bolingbroke, Oxford and the English Jacobites refusing to convert to Protestantism, [Bar le Duc] 2/13 March 1714

I should very much have wishd not to be obliged at this time to enter upon so nice a subject as that of religion, but your last letters are so pressing and positive that it would be an unpardonable dissimulation in me should I not answer your letters with the same sincerity you writt them.

I shall therefore begin by puting you in mind of the last conversation I had with you upon that subject, to which I have nothing to add, but that I neither want counsell nor advice to remain unalterable in my fixed resolution of never dissembling my religion, but rather to abandon all then act against my conscience and honour, cost what it will. These are my sentiments, and had I others, or should I act contrary to those I have where is the man of honour that would trust me? And how could my subjects depend upon me or be happy under me, if I should make use of so notorious an hipocrisy to get my self amongst them? I know their generous character could not but detest the crime it self and him that should be guilty of it. And would they but give themselves time seriously to consider, I am persuaded they would not make my religion the only obstacle of my restoration, it being it self their greatest security for their libertys, propertys and religion by puting it out of my power ever to invade them should I intend it. Which is so far from my thoughts that on the contrary I am most willing and ready to grant all the reasonable that can be demanded of me [sic] in relation to all these points, all my desire being to make them a florishing and happy people. I can have no other interest but theirs, whereas how many other rightfull heirs are there to the crown after me who, being powerfull strangers, may have inclinations equal to their power, and may very probably never give rest to England till they enslave it in good earnest.

Will my subjects allways be so blinded as to make a monster of what is in effect their greatest security, and not perceive and endeavour to prevent the reall and just causes they have of fear and apprehension?

My present sincerity at a time it may cost me so dear, ought to be a sufficient earnest to them of my religious observance of whatever I promise them, for I can say with truth that I heartily abhorr all 
dissimulation and double dealing, and I love my subjects even now too well not to wish, as much for their sakes as my own, that they would at last open their eyes to see their true interest and timely provide for their future peace and quiet.

8 AUL, Macbean p Jam III ma: Manifesto and Declaration by the Noblemen, Gentlemen and Others, who dutyfully appear at this time [1715] in asserting the undoubted right of their lawfull soveraign James the 8th, by the grace of God, King of Scotland, England, France and Ireland, Defender of the Faith, etc, and for relieving this his ancient kingdom of Scotland from the oppressions and grievances it lyes under.

His Majestie's right of blood to the crown of these realms is undoubted, and has never been disputed nor arraigned by the least circumstance of authority whatsoever.

By the laws of God, by the ancient constitution of these nations, and by the positive unrepealed law of the land, we are bound to pay his Majesty the duty of faithfull subjects.

Nothing can absolve us from this our duty of subjection and obedience. The laws of God require our allegiance to our rightfull King. The laws of the land, secure our religion, and other interests, and his Majesty giving up himself to the support of his Protestant subjects puts the means of secureing to us our concerns religious and civil into our own hands.

Our fundamental constitution has been intirely altered and sunk amidst the various shocks of unstable faction, which in searching out new experiments pretended for our security, has produced nothing but dayly disappointments, and has brought us and our prosperity under a precarious dependence upon forreign councils and interests, and the power of forreign troops.

The late unhappy Union, which was brought about by the mistaken notions of some, and by the ruinous and selfish designs of others, has proved so far from lessening and healing the differences betwixt his Majestie's subjects of Scotland and England, that it has widened and encreased them, and appears by experience so inconsistent with the rights, interests and priviledges of us and our good neighbours and fellow subjects of England that the continuance of it must inevitably ruin us and hurt them, nor can any way be found to relieve us and restore our ancient independent 
constitutions, but by restoring our rightful and naturall King, who has the only undoubted right to reign over us. Neither can we hope that the party who chiefly contributed to bring us into bondage will at any time endeavour to work our relief, since it is known how strenuously they opposed in two late instances, the efforts that were made by all Scotsmen but themselves, and supported by the best and wisest of the English, towards so desireable an end, as they will not adventure openly to disown an dissolution of the Union to be.

Our substance has been wasted in the late ruinous wars, and we see an unavoidable prospect of having wars continued on us and our posterity, so long as the possession of the crown is not in the right line.

The hereditary rights of the subjects, though confirmed by conventions and Parliaments are now treated as of no value nor force, and past services to the crown and the royall family are now lookt upon as grounds of suspicion.

A packt assembly, who call themselves a British Parliament have so far as in them lyes inhumanely murthered their own and our soveraign, by promising a great sume of money as the reward of so execrable a crime. They have proscribed by unaccountable and groundless impeachments and attainders, the worthiest patriots of England, for their honourable and successful endeavours to restore trade, plenty and peace to these nations. They have broke in upon the sacred laws of both countreys, by which the liberties of our persons were secured.

They have impowered a forreign prince (who notwithstanding his expectations of the crown for fifteen years, is still unacquainted with our manners, customs and language) to make an absolute conquest, if not timeously prevented, of the three kingdoms, by investing him with an unlimited power, not only of raising unnecessary forces at home, but also in calling in forreign troops, ready to promote his uncontroulable designs. Nor can we be very hopefull of its being otherwise in the future as it is in at present, for some generations to come, and the consequence of these unexampled proceedings has been already so fatall to great numbers of our kinsmen, friends and fellow subjects of both kingdoms, that they have been constrained to abandon their countrey, houses, wives and children or to give themselves up prisoners, and perhaps victims to be sacrificed at the pleasure of forreigners, and a few hot headed 
men of a restless faction whom they employ. Our troops abroad, notwithstanding their long and remarkable good services, have been treated since the peace with neglect and contempt, as particularly in Holland, and it is not now the officers' long service, merit and blood they have lost, but money and favour, by which they can obtain justice in their preferments.

So that it is evident that the safety of his Majestie's person, and loyall subjects, the rights of his people, and independency of his kingdoms call loudly for immediate relief and defence.

The consideration of these unhappy circumstances, with the due regard we have to common justice, the peace and quiet of us and our posterity, our duty to his Majesty and his commands, are the powerfull motives which have engaged us in our present undertaking, which we are firmly and heartily resolved to push to the utmost, and stand by one another to the last extremity, as the only solid and effectual means of putting an end to so dreadfull a prospect as by our present situation we have before our eyes, and with faithfull hearts, true to our onely rightfull king, our countrey, and our neighbours, we earnestly beseech and expect (as his Majesty commands) the assistance of all our true fellow subjects to second these our just attempts, declaring hereby our sincere intentions:

That we will promote and concurr in all lawfull means for settling a lasting peace to these lands, under the auspicious government of our native born soveraign, the direction of our own domestick councils, and the protection of our own native force and troops.

That we will in the same manner concurr and endeavour to have our laws, liberties and properties secured by free Parliaments of both kingdoms.

That by the wisdom of such Parliaments, we shall endeavour to have such laws enacted, as shall give an absolute security to us and future ages for the true Protestant religion against all efforts of arbitrary power, popery and all its other enemies. Nor have we any reason to be distrustfull of the goodness of God, the solidity of our holy religion, or the known excellency of his Majestie's judgment, as not to hope, that due time, good example and conversation with our learned divines, will remove those prejudices which we know that his education in a popish countrey has not riveted in his royall discerning mind. And we are sure, that as justice is a vertue of all religious professions, the doing of it to him, will not lessen his good opinion of ours. 
That as the King is willing to give his royall indemnity for all that is past, so we will chearfully concurr in passing generall acts of oblivion, that our fellow subjects who have been misled may have a fair opportunity of living with us, in the same friendly manner we design to live with them.

That we will use our endeavours for redressing the bad usage of our troops abroad, and bringing the troops at home to be on the same foot and establishment of pay, as those in England.

The peace of these nations being thus settled, and we thus freed from forreign dangers, we will use our endeavours to have the army reduced to the usuall number of guards and garisons, and will conur in such laws and methods as shall relieve us of the heavy taxes and debts now lying upon us, and at the same time will support the publick credit in all its parts.

And we hereby faithfully promise and engage, that every officer who joins with us in our King and countrey's cause, shall not only enjoy the same post he now does, but shall be advanced and preferred according to his rank and station, and the number of men he brings with him to us. And each foot soldier so joining us, shall have twenty shillings sterling gratuity, besides his pay. And each trooper or dragoon, who brings his horse and accoutrements along with him, the sume of twelve pounds sterling.

And in generall, we will concur with all our fellow subjects in such measures as shall make us flowrish at home, and be formidable abroad, under our rightfull soveraign, and the peaceable harmony of our ancient fundamentall constitutions, undisturbed by Pretender's interests, councils from abroad, or by restless factions at home.

In so honourable, good and just a cause, we doubt not of the assistance, direction and blessing of Almighty God, who has so often rescued the royall family of Stewart and our countrey, from sinking under oppression.

\section{Stuart Papers 53/48: Atterbury to James, [London] 22 April} 1721

My long indisposition, and the little hopes I saw of being in any particular degree serviceable, have for some time interrupted the course of my writing, though my thoughts and designs have been all ever pointed the same way and shall be so pointed while I live. 
Sir, the time is now come, when with a very little assistance from your friends abroad, your way to your friends at home is become safe and easy. The present juncture is so favorable, and will probably continue for so many months to be so, that I cannot think it will pass over without a proper use being made of it. Your friends are in good earnest interesting themselves for that purpose, and under a full expectation that an opportunity may some time this summer be given to them to shew their zeal for your service. They will never despair, but must always think this the most promising juncture that ever yet offerd itself.

The worthy Mr Kanmore [Sir Henry Goring] will be able to explain things so fully to your friends on the other side, who can with the most dispatch and secrecy, convey the accounts of them to you, that I think it as unnecessary as it is unsafe, to enter into particulars. I therefore end my letter, as I shall end my life, with vows and prayers for your felicity.

10 The Memorial of the Chevalier de St. George, on Occasion of the Princess Sobieski's Retiring into a Nunnery: and two Original Letters, Written by the Chevalier to the said Princess, to Dissuade ber from that Design. Translated from the Original French (London, [1726]), pp. 11-13.

The Chevalier's [James's] First Letter

Rome, 29 October/9 November 1725

Your conduct towards me, the manner in which I have been threatned and the publick injury done me by your retreat into a nunnery do not affect me so much as the misfortune and the shame to which you are exposing your self by so strange a proceeding. 'Tis true, all these things touch me as they ought, but hitherto I have no resentment against you for I am every moment more and more convinced that the malice and cunning of our enemies have imposed upon your youth and the weakness of your sex. You have had reason a great while to be persuaded that I will be master of my own affairs, and in my own family, but it is not yet too late to be sensible of your error. Restore your self, therefore, to reason, to duty to yourself, and to me, who with open arms expect your submissions, that you may again meet all the peace and happiness that is in my power to confer on you. But if, notwithstanding all these efforts of my tenderness, you persist in the resolution with which you have 
threatned me, 'twill still be a comfort to me to think, that I have spared no pains to hinder you from it. Once more I conjure you, my dear Clementina, to think seriously of what I have said.

\section{Stuart Papers 236/73: circular letter from James to Colonel Cecil for the English Jacobites, [Rome] 16/27 September 1741}

I am sorry to find you continue still out of order, having all the concern for your wellfare in all respects that your zeal and good will for me deserve from me. You will to be sure hear from the worthy persons now in France, so I need say little here of their transactions. I wish they had met with better success.

... However, I cannot say I am discouraged myself, considering the present situation of publick affairs abroad, which is such as ought naturally speaking to engage France in a war with England ere it be long, and if once a rupture happens betwixt the two nations I think it almost impossible but that Cardinal Fleury should undertake my restoration, which he will certainly do with pleasure whenever what he thinks a favourable occasion offers, for I doubt not of his good will for my family and cause, though he is not of an enterprizing temper. You may depend on my endeavors towards inducing him to come once to a resolution in our favor, and that whenever such a resolution may be taken it may be executed in the manner most suteable to the safety and satisfaction of my English subjects.

But whatever may happen as to affairs on this side [of] the sea, I must earnestly recommend to all those with you who wish me well that they should pursue vigourous and unanimous measures in the next sessions of Parliament. They will probably have many occasions of greatly distressing the present government and ministry, and will perhaps find some who will concurr with them in that, though not out of good will for my cause, and even be the first proposers of measures which may tend to that end. In such cases I hope my friends will make no scruple in joyning heartily with them, for whatever their particular motives may be, anything that tends to the disadvantage of the present government and to the bringing it into confusion cannot but be of advantage to my cause. Opportunities may offer during the next sessions, which if lost, may return no more, and besides the consequences that my friends showing a proper spirit may have at home, nothing certainly can more effectually encourage Cardinal Fleury to declare for us. 
[Thus] I take my friends behavior next [session] to be a matter of the greatest importance, and I doubt not but when they consider seriously what they owe both to themselves and me they will not be wanting in anything that may contribute to our common wellfare, and indeed that of our country.

I desire you will communicate this letter, or the contents of it, to as many as you can with safety and prudence, and be yourself always assured of my constant esteem and kindness.

\section{Stuart Papers 266/86: Charles Edward to James, St Nazaire, 21 June/2 July 1745}

Sir,

The contrary winds that have been blowing hitherto have diferd my embarking, which will be this afternoon at seven, for to go to the rendevous of the man of war of 67 guns; and 700 men aboard as also a company of sixty volontiers, all gentlemen, whom I will probably get to land with me, I mean to stay; which though few will make a shew, they having a prety uniform. The number of arms are just as I mentioned in my last of the [1st/]12[th June] that goes with this, except the augmentation I was in hops of is of a hundred or two less than I expected, which is no ods. I keep this open and do not send it until I am fairly set off from Belle Isle - Id este the rendevous - so that I may add a note to it iff being sea sick dos not hinder. Iff it does Sir Thomas will suply, in mentioning what more may occor. It is a mortification to me to want so many of your packets, which are lying at Paris because of the daily expectation of parting. Wee have nothing to do now but to hope in the Almytie's favouring uss, and reccompensing our troubles, which as you may see by the nature of the thing were not small. I hope in God my next will bring comfortable news. In the mean time I remain laying myself at your Majesty's feet, most humbly asking blessing. Your most dutifull son. Charles P.

\section{Charteris (ed.), Short Account of the Affairs of Scotland,} pp. 336-41: the Jacobite council at Derby, 5 December 1745

The 4th of December the whole army marched into Derby. The Duke of Devonshire had left the town with his regiment the day before; the Duke's army [i.e. Cumberland's army] were that night 
at Stafford and the next at Litchfield. [On] The 5th in the morning Lord George Murray and the commanders of battalions and squadrons waited upon the Prince [Charles Edward Stuart], and Lord George told him that it was the opinion of every body present that the Scots had now done all that could be expected of them. That they had marched into the heart of England ready to join any party that would declare for him, that none had, and that the counties through which the army had passed had seemed much more enemies than friends to his cause. That there was no French landed in England, and that if there was any party in England for him, it was very odd that they had never so much as either sent him money or intelligence or the least advice what to do. But if he could produce any letter from any person of distinction in which there was an invitation for the army to go to London, or to any part of England that they were ready to go. But if nobody had either invited them or meddled in the least in their affairs, it was to be supposed that their was either no party at all, or if there was they did not chuse to act with them, or else they would ere now have lett them know it. Suppose even the army marched on and beat the Duke of Cumberland, yett in the battle they must lose some men, and they had after that the King's own army, consisting of 7000 men near London to deal with. On the contrary, if either of these armies beat them, there would not a man escape, as the militia, altho they durst never face the army while in a body, yett they would have courage enough to putt an end to them if they were routed. And so the people that were in arms in Scotland would fall an easy sacrifice to the fury of the government. Again, suppose the army was to slip the King's and Duke's army and gett into London, the success of the affair would intirely depend upon the mobs declaring for or against it, and that if the mob had been much inclined to his cause, since his march into England, that to be sure some of his friends in London would have fallen upon some method to have lett him know it. But if the mob was against the affair 4500 men would not make a great figure in London. Lord George concluded by saying that the Scots army had done their part, that they came into England at the Prince's request to join his English friends, and to give them courage by their appearance to take arms and declare for him publickly as they had done, or to join the French if they had landed; but as none of these things had happened, that certainly 4500 Scots had never thought of putting a king upon the English throne by themselves. So he said his opinion was 
they should go back and join their friends in Scotland, and live and die with them, and the French (who at Derby the army learned had landed in Scotland with Lord John Drummond, but did not know their numbers but believed 4000 men [actually only 700 arrived]). After Lord George had spoke he desired all the rest of the gentlemen present to speak their sentiments, and they all agreed with Lord George except two [the Duke of Perth and Sir William Gordon], who were for going to Wales to see if the Welch would join. It was urged too that Wade's army, which was following, must likewise be fought with as the other two armies would certainly stop the Prince's by fighting or other methods, which would give Wade time enough to come up. The Prince heard all these arguments with the greatest impatience, fell into a passion and gave most of the gentlemen that had spoke very abusive language, and said that they had a mind to betray him. The case was he knew nothing about the country nor had not the smallest idea of the force that was against him, nor where they were situated. His Irish favourites, to pay court to him, had always represented the whole nation as his friends, had diminished much all the force that was against him, and he himself believed firmly that the soldiers of the regulars would never dare fight against him, as he was their true prince. For all the success he had had as yett he attributed to the mens' consciences not allowing them to fight against him, than to the power of the broadsword, and he always believed he should enter St James with as little difficulty as he had done Holyrood house. He continued all that day positive he would march to London. The Irish in the army were always for what he was for, and were heard to say that day that they knew if they escaped being killed the worst that could happen to them was some months' imprisonment. The Scots were all against it; so at night the Prince sent for them and told them he consented to go to Scotland, and at the same time told them that for the future he would have no more councills, for he would neither ask nor take their advice, that he was accountable to nobody for his actions but to his father. And he was as good as his word, for he never after advised with any body but the Irish officers, Messrs [John] Murray [of Broughton] and [John] Hay [of Restalrig] and never more summoned a councill. 


\section{Howell (ed.), State Trials, xix. col. 739-42: Dr Archibald Cameron's final statement, 6 June 1753}

Being denied the use of pen, ink, and paper (except in the presence of one or more officers, who always took away the paper from me whenever I began to write complaints) and not even allowed the use of a knife with which I might cut a poor blunted pencil that had escaped the diligence of my searchers, I have, notwithstanding, as I could find opportunity, attempted to set down on some slips of paper, in as legible characters as I was able, what I would have my country satisfied of in regard to myself, and the cause in which I am now going to lay down my life.

As to my religion, I thank God I die a member (though unworthy) of that church, in whose communion I have always lived, the Episcopal Church of Scotland as by law established before the most unnatural rebellion begun in 1688, which, for the sins of these nations, hath continued to this day: and I firmly trust to find, at the most awful and impartial tribunal of the Almighty king of kings, through the merits of my blessed Lord and Saviour Jesus Christ, that mercy (though undeserved) to my immortal part, which is here denied to my earthly, by an usurper and his faction, though it be well known I have been the instrument of preventing the ruin and destruction of many of my poor deluded countrymen who were in their service ...

... I thank kind providence I had the happiness to be early educated in the principles of Christian loyalty, which, as I grew in years, inspired me with an utter abhorrence of rebellion and usurpation, though ever so successful, and when I arrived at man's estate, I had the testimony both of religion and reason to confirm me in the truth of my first principles. Thus my attachment to the royal family is more the result of examination and conviction, than of prepossession and prejudice; and as I am now, so was I then, ready to seal my loyalty with my blood. As soon therefore as the royal youth [Charles Edward] had set up the king, his father's, standard, I immediately, as in duty bound, repaired to it. And as I had the honour, from that time, to be almost constantly about his person till November 1748 (excepting the short time after the affair of Culloden, that his Royal Highness was in the Western Isles) I became more and more captivated with his amiable and princely virtues, which are indeed in every instance so eminently great, as I want [i.e. lack] words to describe.

I can farther affirm (and my present situation, and that of my 
dear prince too, can leave no room to suspect me of flattery) that as I have been his companion in the lowest degree of adversity that ever prince was reduced to, so I have beheld him too, as it were, on the highest pinnacle of glory, amidst the continual applauses, and I had almost said, adorations of the most brilliant court in Europe; yet he was always the same, ever affable and courteous, giving constant proofs of his great humanity, and of his love for his friends and his country. What great good to these nations might not be expected from such a prince, were he in possession of the throne of his ancestors! And as to his courage, none that have ever heard of his glorious attempt in 1745 , can, I should think, call it in question.

... I thank God I was not in the least daunted at hearing the bloody sentence, which my unrighteous judge pronounced with a seeming insensibility, till he came to these words "But not till you are dead", before which he made a pause, and, uttering them with a particular emphasis, stared me full in the face, to see, I suppose, if I was as much frightened at them, as he, perhaps, would have been had he been in my place. As to the guilt he said I had to answer for, as having been instrumental in the loss of so many lives, let him and his constituents see to that. At their hands, not at mine, will all the blood that has been shed on that account be required.

God, of his infinite mercy, grant they may prevent the punishment which hangs over their heads, by a sincere and timely repentence, and speedy return to their duty.

I pray God to hasten the restoration of the royal family (without which this miserably divided nation can never enjoy peace and happiness) and that it may please him to preserve and defend the King, the Prince of Wales, and the Duke of York, from the power and malice of their enemies; to prosper and reward all my friends and benefactors, and to forgive all my enemies, murderers and false accusers from the Elector of Hanover [George II] and his bloody son [Cumberland], down to Samuel Cameron, the basest of their spies, as I freely do from the bottom of my heart.

\section{Stuart Papers 345/164: Charles Edward's notes for points to be included in his next declaration, 1753}

1st. The Parliament to be annual or at most triannual.

2nd. The number of persons in offices both civil and military capable to sit in the House of Commons not to exceed fifty. 
3rd. When all is quiet to disband the standing army and establish a national millitia in their place.

4th. The liberty of the press to be confirmed.

5 th. To strive to remove all abuses that may be in the power given to the civil ministers.

6th. To assert the rights of the people to withstand the encroachments of power destructive to their religious or civil rights.

7 th. An union between the three kingdoms to be proposed to a free Parliament.

8th. To mention my religion, which is of the Church of England as by law established, as I have declared myself when in London the year 1750 .

\section{Charteris (ed.), Short Account of the Affairs of Scotland,} pp. 148-9: Lord Elcho's account of the English Jacobites' final severing of relations with Charles Edward Stuart [1754]

The partisans of the Prince [Charles Edward] in England at that time granted him a pension of 5000 pounds sterling a year. One gentleman, [James] Dawkins [M.P.] by name, gave a thousand of the five. All of this money was this year taken away from him for ever, and all these gentlemen became his enemies and particularly this same Dawkins. They had sent one of their friends [Daniel Macnamara] to persuade the Prince to part with his mistress [Clementina Walkinshaw], because her sister had a place in the service of the Princess of Wales at the court in London, and they feared a correspondence between the two sisters. The Prince replied that he would not put away one of his dogs to please them, and ended by demanding more money, stating that what they gave him was not sufficient. The messenger said to him that these gentlemen were not his bankers, that what they gave him was given out of pure generosity, and that he ought to be more than content. The Prince retorted that he knew the names of all those that had sent him the money, and that if they would not continue to do so, he would send a list of their names to the King of England. All these gentlemen were so indignant at these threats that from that time the Prince never received a halfpenny from England. 
17 W. S. Lewis, W. H. Smith, G. L. Lam and E. M. Martz (eds), Horace Walpole's Correspondence With Sir Horace Mann and Sir Horace Mann the Younger (48 vols, New Haven, CT, 1971), xxv. 100-2: Mann to Walpole, 12 December 1780

... I cannot refrain from telling you a story which will make a noise in the world and make you laugh. What France and Spain will say to it I cannot pretend to judge, though their views of giving a Stuart heir to the crown of England will be defeated by what has happened here two days ago by the separation of the Countess Albany [Louise von Stolberg] from her husband [Charles Edward]. You know undoubtedly the extravagance of his behaviour, which has of late manifested itself in his cruel and indecent treatment of his wife. On St Andrew's day, which he always celebrated by an extraordinary dose of wine and stronger liquors, he used her extremely ill, and at night committed the most nauseous and filthy indecencies from above and below upon her, tore her hair, and attempted to throttle her. Her screams roused the family [i.e. servants], and their assistance prevented any other violence. She is supposed then to have taken the resolution of leaving him, but strictly concealed it till she could inform Cardinal York of it and receive his answer. His reply was compassionate but exhorting her to bear with his brother's behaviour as long as possible, promising her, however, both protection and assistance in case of need. She made her case privately known to the Great Duke [of Florence] and then concerted with a lady [a "Mrs Orlandini"] of her acquaintance the method of putting her resolution in execution, which was admirably well managed. She invited that lady to breakfast with on Saturday morning, as she had often done before, in company with the Count [i.e. Charles Edward], who after proposed to the ladies to go out in the coach, and they conducted him to a sort of convent where men are permitted within the first door. The Count followed, but they shut it in his face, and on his persisting to have it opened, the lady who has the superintendance of that place for the Great Duchess and had orders to be there, came to the grate to tell him that the Countess Albanie had put herself under the Great Duke's protection, and was determined never to cohabit with him again, upon which he went grumbling home, menacing vengeance on all those who had a hand in the affair. He says that he knows that I had given many thousand zecchins to his wife to induce her to give him a potion to render 
him impotent. He sent his first minister [Count Spada] to the Great Duke to complain of what had passed and to demand his wife, but he received a very unfavourable answer... 